\title{
Managerial Competency Model for the Management of Equality Educational Institutions in the Global Era
}

\author{
Qonita Rahmi' ${ }^{1}$ Heru Santosa ${ }^{2}$, Siti Zulaikha 3 \\ DOI: 10.35445/alishlah.v13i2. 634
}

\begin{abstract}
Article Info
Abstract

Keywords: Competency; Equality Institution; Managerial; Management

This study aims to determine managerial competencies for management of Equality Education Institutions in Tangerang relevant to the current global era. Competent managers have an impact on the quality of education. This study was qualitative research with quantitative descriptive methods. Collecting data used observation, interview, documentation, and questionnaire. Analysis data had four steps were data collection, data reduction, data display and data analysis. The finding concluded that managerial competency must be increased to identify problems and institutional needs, build a quality learning climate and system, program evaluation models are not regular. There is no follow-up on the results of program supervision. In addition, managerial competence must also use technological devices with various advances useful in managing educational institutions.
\end{abstract}

Kata kunci:

Kompetensi;

Lembaga Kesetaraan;

Manajerial;

Pengelola

\begin{abstract}
Abstrak
Penelitian ini bertujuan untuk mengetahui kompetensi manajerial bagi pengelola Lembaga Pendidikan kesetaraan di Tangerang yang relevan untuk era global saat ini. Pengelola yang kompeten berdampak pada kualitas penyelenggaraan Pendidikan. Penelitian ini merupakan kualitatif dengan metode deskriptif kuantitaif. Teknik pengumpulan data adalah observasi, dokumentasi, wawancara dan kuesioner. Teknik analisis data ada 4 tahap yaitu pengumpulan data, reduksi data, penyajian data, dan analisis data. Hasil penelitian menyimpulkan bahwa kompetensi manajerial yang masih perlu di tingkatkan adalah kemampuan mengidentifikasi masalah dan kebutuhan lembaga, membangun iklim dan sistem pembelajaran yang berkualitas, model evaluasi program yang belum teratur, dan tindak lanjut hasil supervisi program belum ada. Selain itu, kompetensi manajerial juga harus mampu menggunakan perangkat teknologi dengan berbagai kemajuan yang berguna dalam mengelola Lembaga Pendidikan.
\end{abstract}

\footnotetext{
${ }^{1}$ Universitas Negeri Jakarta, Indonesia Email: qonita.rahmi@yahoo.com 2 Universitas Negeri Jakarta, Indonesia Email: qonita.rahmi@yahoo.com 3 Universitas Negeri Jakarta, Indonesia Email: qonita.rahmi@yahoo.com
} 


\section{INTRODUCTION}

Education is one of the basic needs that is very important for all circles of society to face the changing times. Society must constantly adapt in facing various job challenges, especially in the era of the industrial revolution 4.o. Indonesia has three educational paths that can be taken by the community, namely formal, informal, and non-formal education. Equality Education is one of the academic units in the non-formal education pathway aimed at citizens who have not had the opportunity or failed to complete formal education.

Some factors that cause people to choose equal education are the need to get a diploma equivalent to formal education, poor economic conditions, workload, and various other problems. Data from the Ministry of Education and Culture of Indonesia shows that the number of students with inequality education institutions increases every semester. This shows that equality education is increasingly in demand by the wider community. So, to meet the community's educational needs, quality equality education is needed to improve the community's standard of living and reduce the dropout rate. Several components determine the success of non-formal education goals, especially equality education. One of the components that determine the quality of equality education is the competence of educators in manage learning (Manea, 2015).

The existence of equality education institutions is the right solution to improve the quality of everyone. The Center for Community Learning Activities in Tangerang has also helped many out-ofschool children to continue their education. The Head of the Tangerang City Education Office, Masyati Yulia, said that as many as 75\% of the total number of Out-of-school Children in Tangerang had returned to school at Community Learning Activity Centers spread across several sub-districts through the Tangerang Smart Center program (tangerangkota.go.id, 2019). Nevertheless, Sofiyan added that many obstacles occur in Equality Education institutions in Tangerang.

One of the obstacles faced by the Karya Agung Community Learning Center institution located in Cibodas District, Tangerang City, is management's managerial competence. In contrast, managerial competence is an essential part of management in running this educational organization. As one of the top leaders, institutional management needs good communication, team management, and leadership (Jami et al., 2012).

The previous study has discussed the managerial competence of management institutions. It can be increased using training and feedback from the management institution (De Villiers, 2013). It can focus on formal and informal training to increase management (Larsen et al., 1991). They must have the experience to understand the culture and situation institution (Chong, 2008). Managerial competence is broadly equally important in cultural environments. Competence differences are visible where the work environment is different. Competencies assessed related to planning, organizing, and motivating others to distinguish managers who are more likely to develop careers regardless of their culture or work environment (Chong, 2013). Their competence influenced the performance in an institution (Bucur, 2013). It means that every management institution is an innovator leader (Trivellas \& Reklitis, 2014).

Managerial mastery for managers of educational institutions is related to the rules set from the responsibility of a manager. In this case, the manager of an educational institution must have a leadership spirit, the ability to motivate colleagues, plan programs, manage institutions, monitor and evaluate programs and control the programs that have been determined. However, the new orientation that wants to be studied in this research is related to developing technology and knowledge constantly changing and getting more advanced.

Therefore, this research advances different concepts that are relevant to current conditions. This research is urgently carried out because managers of equivalence educational institutions in Tangerang need a new concept in managing institutions that can survive in developing science and technology and easy access to information in improving the quality of education. So, this research 
aims to obtain the managerial competence of management of equivalency educational institutions in Tangerang that are relevant in the digital era.

\section{METHODS}

The study is field research that investigates the problem of managerial competence of the management of equality education institutions in Tangerang which is accurate and factual. Therefore, the type of research used qualitative research with quantitative descriptive methods. In this case, the research provides findings in the form of a narrative of the percentage of data. Data collection techniques include 1) passive participation observation, 2) documentation is used to collect various secondary data from written documents, legislation, and photographs in the field, three researchers conducted) interviews to determine the problems that must be investigated through the Tangerang Education Office for Non-formal Education regarding Standards Educators and Education Personnel at the Equality Education Institute in Tangerang, and 4) closed questionnaire. The participants involved in filling out the questionnaire were the ranks of education staff and managers/management in equivalency education institutions. Participants are $12(\mathrm{M}=7$ and $\mathrm{F}=5$ ).

The data analysis carried out in this study used the technique of qualitative descriptive, which describes the situation that occurs through the data that has been obtained. The data processing model uses the Interactive Model from Miles and Huberman; namely, data analysis is carried out during data collection and after data collection is completed within a certain period. The steps in data analysis are;

1. Data collection is taken from observation, documentation, and interview. The researcher collects the data.

2. Data reduction. The selection process identifies the data that has been collected according to the category of managerial competency.

3. Data display. After reducing the data obtained from the field, the next step is to present the data in a table. Data is presented in percentage form

4. Data analysis and verification. At this stage, the data is analyzed and verified to obtain conclusions about managerial competencies related to the management of educational institutions.

\section{FINDINGS AND DISCUSSION}

The result of data analysis shows that managerial competency influenced the management process to improve the quality of education.

\section{Table 1. The Leadership Ability of the Management}

\begin{tabular}{|c|c|c|c|}
\hline & Components & Indicators & Percentage \\
\hline \multirow[t]{5}{*}{1} & Leadership ability & $\begin{array}{l}\text { 1. I can apply the principles of non-formal education to } \\
\text { move the other party to carry out the program. }\end{array}$ & $92 \%$ \\
\hline & & 2. I can show model as an education manager & $83 \%$ \\
\hline & & $\begin{array}{l}\text { 3. I can improve the ability of educators and education staff } \\
\text { in the education unit that is led by the demands of } \\
\text { performance }\end{array}$ & $92 \%$ \\
\hline & & 4. I can organize Equality Education support resources & $75 \%$ \\
\hline & & $\begin{array}{l}\text { 5. I can carry out the function as a source of information } \\
\text { and spokesperson }\end{array}$ & $83 \%$ \\
\hline \multirow[t]{3}{*}{2} & Motivating Ability & 1. I can push students' desire to learn actively learn & $92 \%$ \\
\hline & & $\begin{array}{l}\text { 2. I can mobilize all elements in the organization to achieve } \\
\text { program goals }\end{array}$ & $67 \%$ \\
\hline & & $\begin{array}{l}\text { 3. I can mobilize community participation in supporting } \\
\text { program implementation }\end{array}$ & $75 \%$ \\
\hline \multirow[t]{4}{*}{3} & Planning Ability & $\begin{array}{l}\text { 1. I can identify the problems and learning needs of the } \\
\text { community. }\end{array}$ & $58 \%$ \\
\hline & & 2. I can formulate a goals program to be achieved & $75 \%$ \\
\hline & & 3. I can identify the source and program constraints. & $\begin{array}{l}67 \% \\
-80 \%\end{array}$ \\
\hline & & 4. I can plan activities & $58 \%$ \\
\hline
\end{tabular}


Organize

5

\section{Monitoring} Evaluation Ability

6
5. I can design monitoring and evaluation activities

1. I can manage execution programs that include systems information, funding, manpower, facilities, learning infrastructure, and teaching and learning activities

2. I can organize cooperation with community components

3. I can cultivate feelings have a program

4. I can create a learning climate and learning system

and 1. I can carry out monitoring of program implementation

2. I can carry out program implementation evaluations

3. I can compile reports on program implementation

1. I can supervise program implementation

2. I can carry out a follow-up on the results of the supervision
$75 \%$

$75 \%$

$83 \%$

$67 \%$

$58 \%$

$67 \%$

$58 \%$

$75 \%$

$67 \%$

$58 \%$

Table 1 concludes that the ability to lead the agency's management has shown a reasonable level. The management has acted as a capable leader. The leadership ability of the management is the essential element in the context of managing educational institutions to be a significant capital in leading the institution (Spendlove, 2007; Crosthwaite, 2018). Leadership skills are fundamental in supporting the management of institutional managers. As a leader, the managerial ability is reflected in every leader's behavior in various educational activities. So, management can determine the direction and achievement of school performance (Hidayat \& Wulandari, 2020).

The ability of motivation becomes an essential component in supporting the managerial ability of the management of educational institutions. The motivational process builds the desire of all parties in the institution to carry out the educational process according to predetermined goals. However, the model of motivating colleagues still has shortcomings, so that it has an impact on the achievement of program goals. The leader and motivation have a relationship to support the process of education. Leadership and motivation are also crucial to improving the performance of the employee (Tumilaar, 2015).

Management at the institution must design programs according to achieving previous goals and improving any weaknesses that arise. In management planning, abilities are still fragile, especially identifying problems, community needs, and activities to implement the program. It has an impact on the use of all available resources, which are not maximized. Another weakness that still needs to be improved is creating a learning system and learning climate in education. Thus, the part that must be improved is how to evaluate and follow up for program supervision. The ability to manage an institution is the primary key to the success of any program. In this case, the management has built cooperation with all stakeholders related to the implementation of education. It can have an impact on developing a more pleasant academic climate for students to learn

From these findings, it can be understood that the managerial competence of institutional management has a significant influence. It means that management is tasked with leading the institution and is also responsible for all institutional activities, administration, and quality standards of learning implementation (Wahyuni et al., 2021). However, different opinions reveal that the quality of school leaders and school administrators influences the quality of teaching and learning at every level of the education system and every type of school (Bitterová et al., 2014). Managers of educational institutions can carry out leadership functions such as; 1) understanding the principles of non-formal education, 2) understanding the characteristics of managed educators, 3) understanding social support capacity and other sources, 4) being able to move study groups, 5) have charismatic and be a source of information, 6) have high dedication and noble personality (patient, polite, honest, responsible, fair, generous, and exemplary).

In other words, management has synergy to manage all institutional components with the environment through dynamic collaboration. Each component presented in Table 1 explains that the essential competencies for education managers in the 21st century are management and leadership competencies. However, other competencies also have a considerable influence, such as social 
competence, technological competence, individual competence, economic competence, competence business competence, Spiritual competence, moral and religious competence, research competence, environmental competence, global and international competence, political and cultural competence (Bagherpour \& Jahanian, 2017; Iucu, 2014).

The results of the interviews gave different findings from the results of the questionnaire. According to tutors, administrative staff, and structural leaders at the Tangerang equivalency education institution, it was concluded that managerial competence also requires mastery of technology. So far, the management process has been carried out conventionally. So far, knowledge management competence is more oriented to the practice of the tasks being carried out (Nazim \& Mukherjee, 2016). However, the concepts needed in the digital era have changed; namely, educational institutions must consider advances in knowledge and technology in managerial competence. Emerging Trends in the 21st century, such as gamification, augmented reality, new educational applications, and the Internet of Things, are summarized and discussed as innovations, significantly changing the educational environment (Zain, 2021; Limani et al., 2019). It is not only for teaching in the class (Tuma, 2021). Thus, the industrial era 4.0 and even entering the industrial era 5.0 is the right solution in improving the quality of management in providing education (Enke et al., 2018). In this case, equality education institutions in Tangerang must be oriented towards management relevant to the global era. Management must conduct regular training to improve managerial competence for all staff involved in managing the management of equality education institutions

\section{CONCLUSION}

The results of the questionnaire data analysis concluded that the managerial competencies of the managers of equivalence educational institutions in Tangerang that need to be improved are the ability to identify problems and institutional needs, build a quality learning climate and system, program evaluation models are not regular. There is no follow-up on the results of program supervision. Therefore, these indicators become a part that needs to be considered as increasing managerial competence in the global era. In addition, managerial competencies related to digital competencies must also be considered to keep pace with the development of technology and science that continues to develop rapidly.

The analysis of the findings is still limited to the managerial competence of the managers of equivalency education institutions, so the results found are only related to management. Research has not been associated with the concept of knowledge management in the digital era. Therefore, this study suggests that institution managers can continue to provide various activities to improve the management of educational institutions that are relevant to the current context. So, the study results recommend that the leader of equivalence educational institutions in Tangerang pay attention to the concept of manager responsibility that can be relevant to the development of today's increasingly advanced life. They must pay attention to the managerial abilities possessed by everyone in the institution so that the organizational management process can run well. Therefore, other researchers can still develop the results of this study to be associated with the realm of digital competencies that must be owned by managers of educational institutions today.

\section{REFERENCES}

Bagherpour, T., \& Jahanian, R. (2017). The Education Managers' Competencies in the 21th century from the School Principals' Viewpoint in Tehran. International Journal of Learning and Teaching, 3(1). https://doi.org/10.18178/ijlt.3.1.63-68

Bitterová, M., Hašková, A., \& Pisoňová, M. (2014). School Leader's Competencies in Management Area. Procedia - Social and Behavioral Sciences, 149, 114-118. https://doi.org/10.1016/j.sbspro.2014.08.170

Bucur, I. (2013). Managerial Core Competencies as Predictors of Managerial Performance, on Different Levels of Management. Procedia - Social and Behavioral Sciences, 78, 365-369. https://doi.org/10.1016/j.sbspro.2013.04.312 
Chong, E. (2008). Managerial competency appraisal: A cross-cultural study of American and East Asian managers. Journal of Business Research, 61(3), 191-200. https://doi.org/10.1016/j.jbusres.2007.06.007

Chong, E. (2013). Managerial competencies and career advancement: A comparative study of managers in two countries. Journal of Business Research, 66(3), 345-353. https://doi.org/10.1016/j.jbusres.2011.08.015

Crosthwaite, C. (2018). Identifying the Role and Managerial Leadership Competencies of Postgraduate Heads of Departments (pp. 17-37). Springer, Singapore. https://doi.org/10.1007/978-981-10-5249-1_5

De Villiers, R. (2013). 7 Principles of highly effective managerial feedback: Theory and practice in managerial development interventions. International Journal of Management Education, 11(2), 66-74. https://doi.org/10.1016/j.ijme.2013.01.002

Enke, J., Glass, R., Kreß, A., Hambach, J., Tisch, M., \& Metternich, J. (2018). Industrie 4.0 Competencies for a modern production system: A curriculum for Learning Factories. Procedia Manufacturing, 23, 267-272. https://doi.org/10.1016/j.promfg.2018.04.028

Hidayat, N., \& Wulandari, F. (2020). The impact of leadership behavior on school performance. Cakrawala Pendidikan, 39(3), 493-506. https://doi.org/10.21831/cp.v39i3.31005

Iucu, O. (2014). The Perspectives of Adult Education in the Managerial Assistance in Romania. Procedia - Social and Behavioral Sciences, 142, 416-420. https://doi.org/10.1016/j.sbspro.2014.07.703

Jami, H. A., Ahanchian, M., Mahram, B., \& Pakmehr, H. (2012). System of Educational and Qualification-Based Management: A Meta-Analysis About Management Models on the Basis of Competency. Procedia - Social and Behavioral Sciences, 46, 4751-4755. https://doi.org/10.1016/j.sbspro.2012.06.330

Larsen, H. H., O’Driscoll, M. P., \& Humphries, M. (1991). Technological innovation and the development of managerial competencies. Technovation, 11(7), 419-428. https://doi.org/10.1016/0166-4972(91)90023-W

Limani, Y., Hajrizi, E., Stapleton, L., \& Retkoceri, M. (2019). Digital transformation readiness in higher education institutions (hei):the case of kosovo. IFAC-PapersOnLine, 52(25), 52-57. https://doi.org/10.1016/j.ifacol.2019.12.445

Manea, A. D. (2015). Innovation in the Management of Educational Institutions. Procedia - Social and Behavioral Sciences, 209, 310-315. https://doi.org/10.1016/j.sbspro.2015.11.239

Nazim, M., \& Mukherjee, B. (2016). Knowledge Management Competencies. In Knowledge Management in Libraries (pp. 149-169). Elsevier. https://doi.org/10.1016/b978-o-o8100564-4.00007-7

Spendlove, M. (2007). Competencies for effective leadership in higher education. International Journal of Educational Management, 21(5), 407-417. https://doi.org/10.1108/09513540710760183

Trivellas, P., \& Reklitis, P. (2014). Leadership Competencies Profiles and Managerial Effectiveness in Greece. Procedia Economics and Finance, 9, 380-390. https://doi.org/10.1016/s22125671(14)00039-2

Tuma, F. (2021). The use of educational technology for interactive teaching in lectures. In Annals of Medicine and Surgery (Vol. 62, pp. 231-235). Elsevier Ltd. https://doi.org/10.1016/j.amsu.2021.01.051

Tumilaar, B. R. (2015). The Effect Of Discipline, Leadership, And Motivation On Employee Performance At Bpjs Ketenagakerjaan Sulut. Jurnal EMBA: Jurnal Riset Ekonomi, Manajemen, Bisnis Dan Akuntansi, 3(2), 787-797. https://doi.org/10.35794/EMBA.3.2.2015.8901

Wahyuni, S., Sumarsono, R. B., Desyanty, E. S., \& Asimiran, S. Bin. (2021). Analysis on Management's Managerial Competence and Its Influence on Pos-PAUD Service Quality. Journal of Nonformal Education, 7(1), 47-54. https://doi.org/10.15294/jne.v7i1.27257

Zain, S. (2021). Digital transformation trends in education. In Future Directions in Digital Information (pp. 223-234). Elsevier. https://doi.org/10.1016/b978-0-12-822144-0.00o36-7 